\title{
BERKURANGNYA LUAS TANAH DIAKIBATKAN OLEH HAL-HAL DI LUAR KEHENDAK PEMEGANG HAK
}

\author{
Oleh: \\ I Made Aryawan Saddewa ${ }^{1}$
}

\begin{abstract}
This journal shall be entitled as "The Depreciation of the Land Area by Matters Beyond the Will of the Holder of Property Rights". Land is a non-renewable natural resource, so that the ownership of a plot of land in Indonesia becomes every society's desire. The magnitude of the desire to own a plot of land should be followed by the rule of law that protects the holders of the land rights as aspired in Law No. 5 of 1960. The legal issues, which is also the purpose of this journal shall be about the legal consequences caused to the rights of the land that has been depreciated data due to things beyond the will of the holder (such as natural influences) and the legal steps that can be done between the parties (the holders of the property rights and government) in enforcing the principle of legal certainty and to discover the strongest owner of the property rights within the scope of this research. This journal's preparation is done by legal research, and the approach method being used in this journal shall be used is the combination of the statute approach and the conceptual approach. The author's conclusion is that the depreciation data of the land area of this property may result in the eradication of ownership rights to the land as regulated in Article 27 of the Law No. 5 of 1960, as there is no explanation regarding the scope of the destruction of the land in that article. Legal steps that can be done to enforce the legal certainty and to verify the strongest and the most fulfilled party of the property rights is through the deliberation and procurement of land as compensation from the land dispute.
\end{abstract}

\section{Keywords: Depreciation, Surface of the Property, Ownership, Legal Consequence.}

\begin{abstract}
Abstrak
Jurnal ini mengambil judul "Berkurangnya Luas Tanah Diakibatkan Oleh HalHal Di Luar Kehendak Pemegang Hak". Tanah merupakan suatu sumber daya alam yang tidak dapat diperbaharui. Sehingga kepemilikan atas sebidang tanah di Indonesia menjadi keinginan setiap masyarakat. Besarnya keinginan memiliki sebidang tanah ini harus diikuti pula dengan aturan hukum yang melindungi para pemegang hak atas tanah tersebut sebagaimana yang dicita-citakan dalam Undang-undang Nomor 5 tahun 1960 tentang Peraturan Dasar Pokok-pokok Agraria (UUPA). Makalah ini mengangkat permasalahan yang juga menjadi tujuan penulisan yaitu tentang akibat hukum yang ditimbulkan terhadap hak atas tanah yang mengalami Perubahan Data Fisik tanahnya akibat hal-hal di luar kehendak seperti pengaruh alam, dan terkait langkah hukum yang dapat
\end{abstract}

1 Program Studi Magister Kenotariatan, Fakultas Hukum Universitas Airlangga, email: made. aryawan92@gmail.com 
dilakukan antara para pihak (pemegang hak atas tanah dan pemerintah) dalam hal mewujudkan asas kepastian hukum dan sifat hak milik atas tanah yang terkuat dan terpenuh dalam lingkup penelitian ini. Penyusunan jurnal ini dilakukan dengan tipe penelitian hukum yaitu jenis penelitian normatif, dan metode pendekatan yang digunakan ialah pendekatan peraturan perundang-undangan (statute approach) dan pendekatan konseptual (conceptual approach). Hingga tercapainya suatu kesimpulan bahwa dengan adanya Perubahan Data Fisik tanah hak milik ini dapat mengakibatkan hapusnya hak milik atas tanah tersebut sebagaimana diatur dalam pasal 27 UUPA, karena belum adanya penjelasan terkait batasan lingkup dari musnahnya tanah dalam pasal tersebut. Langkah hukum yang dapat dilakukan untuk mewujudkan kepastian hukum dan bukti sifat terkuat dan terpenuh pada hak milik ialah melalui langkah musyawarah dan pengadaan tanah sebagai ganti kerugian dari tanah tersebut.

\section{Kata Kunci : Berkurang, Luas Tanah, Hak Milik, Akibat Hukum.}

\section{PENDAHULUAN}

Indonesia sering disebut sebagai

Negara Agraris. Hal ini dikarenakan Indonesiamerupakannegarakepulauan yang memiliki kontur tanah yang baik untuk kegiatan pertanian bagi masyarakatnya. Seiring berjalannya waktu, telah banyak perkembangan yang terjadi di negeri tercinta ini. perkembangan yang dimulai dari bidang pertahanan dan keamanan hingga bidang perekonomian, sosial dan budaya. Hal ini diikuti dengan perkembanganpemahamanmasyarakat tentang pentingnya berinvestasi.

Tanahmerupakansalahsatuobjek investasi terbaik, hal ini dikarenakan jumlah tanah yang ada tidak akan bisa diperbaharui atau ditambahkan jumlahnya, tetapi jumlah manusia/ penduduk pasti akan berkembang dan bertambah jumlahnya. Maka dari itu, jumlah penduduk dan jumlah tanah yang tersedia akan berbanding terbalik. Hal ini mengakibatkan masyarakat Indonesia sangat menjaga tanah yang dimilikinya. Salah satunya dengan cara mendaftarkan tanah miliknya dengan harapan mendapatkan kepastian hukum atas hak atas tanahnya.

Perkembangan yang terjadi di Negeri ini sepertinya masih belum diikuti dengan perkembangan hukum atau peraturan perundangundangannya agar dapat mengatur dan melindungi segala perbuatan hukum di masyarakat. Seperti halnya dengan sebidang tanah seluas $1000 \mathrm{~m}^{2}$ yang terletak di Jalan Dahlia, Banjar Tuka, Desa Dalung, Kabupaten Badung, Provinsi Bali. Tanah ini merupakan tanah dengan status hak milik yang terletak dengan salah satu sisinya berbatasan dengan sungai. Dalam hal ini debit air sungai yang meningkat menyebabkan tergerusnya daratanyang masih termasuk dalam jarak sempadan sungai sebelumnya hingga mengenai sebagian luas tanah hak milik salah satu masyarakat desa tersebut.

Dalam penelitian ini penulis menggunakan bahan hukum berupa 
peraturan perundang-undangan dan literatur hukum yang berkaitan dengan permasalahan yang dibahas. Penulis juga menyadari bahwa penelitian ini memiliki beberapa kemiripan dengan penelitian lainnya tetapi penulisan ini tentu memiliki perbedaan dalam hal pembahasan pada penelitian ini. Adapun penelitian lain yang terkait dengan Perubahan Berkurang Luas Tanah/Perbedaan Data Fisik Tanah antara lain:

1. Judul Penelitian : Penggunaan Kuasa Menjual Di Dalam Peralihan Hak Milik Atas Tanah Melalui Jual-Beli. Dengan tujuan penelitian yaitu untuk memberikan gambaran tentang sahnya peralihan hak milik atas tanah melalui jual-beli, secara khusus untuk menelaah apakah penggunaan kuasa mutlak di dalam peralihan hak milik atas tanah melalui jual-beli adalah legal/sah secara hukum atau sebaliknya. $^{2}$

2. Kekuatan Mengikat Perjanjian Nominee Dalam Penguasaan Hak Milik Atas Tanah. Dengan tujuan penelitian yaitu untuk mengetahui dan memahami kekuatan mengikat dari perjanjian nominee terhadap penguasaan hak milik atas tanah

2 Adnyana, Penggunaan Kuasa Menjual Didalam Peralihan Hak Milik Atas Tanah Melalui Jual-Beli, Jurnal Magister Hukum Udayana (Udayana Master Law Journal), Vol.4, No.1, Edisi Mei 2015, https://ojs.unud.ac.id/index. $\mathrm{php} / \mathrm{jmhu} /$ article/view/13050, diakses tanggal 12 Oktober 2017 oleh warga negara asing. ${ }^{3}$

3. Pengaturan Prosedur Pembatalan Setipikat Hak Atas Tanah Yang MerupakanBarang MilikNegara. Dengan tujuan penelitian yaitu untuk mengkaji secara teoritis tentang pembatalan sertipikat hak atas tanah yang termasuk barang milik negara, dan juga bertujuan untuk menemukan dan mengkaji peraturanperaturan yang berkaitan dengan pembatalan sertipikat hak atas tanah yang berkaitan dengan barang milik negara. ${ }^{4}$

Adapun tujuan dari penelitian yang dilakukan penulis ini ialah untuk mengetahui dan menganalisis terkait kekuatan dan asas kepastian hukum hak atas tanah khususnya hak milik pada tanah dalam hal mengalami permasalahan seperti berkurangnya luas tanahnya/perubahan data fisiknya yang diakibatkan oleh hal-hal diluar kehendak pemegang hak atas tanahnya, dan juga untuk memberikan wawasan serta sudut pandang baru dalam hal bidang pertanahan khususnya hak

3 I Wayan Werasmana Sancaya, Kekuatan Mengikat Perjanjian Nominee Dalam Penguasaan Hak Milik Atas Tanah, Jurnal Magister Hukum Udayana (Udayana Master Law Journal), Vol.2 No.3 Edisi November 2013, https://ojs.unud.ac.id/index.php/jmhu/ article/view/7364, diakses tanggal 12 Oktober 2017.

4 Anak Agung Istri Diah Mahadewi, Pengaturan Prosedur Pembatalan Sertipikat Hak Atas Tanah Yang Merupakan Barang Milik Negara, Jurnal Magister Hukum Udayana (Udayana Master Law Journal), Vol.2 No.3 Edisi November 2013, https://ojs.unud.ac.id/index. $\mathrm{php} / \mathrm{jmhu} /$ article/view/7285, diakses tanggal 12 Oktober 2017 
milik atas tanah, agar mampu menjadi wawasan bersama di kalangan akademisimaupun praktisikedepannya dalam menghadapi permasalahan yang serupa terkait pertanahan ini.

\section{METODE PENELITIAN}

Tipe penelitian yang digunakan dalam menyusun jurnal ini adalah tipe Penelitian Hukum karena penelitian ini dilakukan berdasarkan aturan-aturan hukum yang di telaah guna menemukan solusi dari permasalahan isu hukum yang dihadapi dalam penelitian hukum ini. Di sinilah dibutuhkan kemampuan untuk mengidentifikasi masalah hukum, melakukan penalaran hukum, menganalisis masalah yang dihadapi dan kemudian memberikan pemecahan atas masalah hukum tersebut. ${ }^{5}$

Pendekatan masalah yang digunakan dalam penulisan tesis ini adalah menggunakan pendekatan perundang-undangan (statute approach) dan pendekatan konsep (conceptual approach) ${ }^{6}$ Pendekatan perundang-undangan (statute approach) ini dilakukan dengan melakukan dan penelahaan mendalam terhadap peraturan perundang-undangan yang berkaitan dengan kasus ini. Pendekatan konsep (conceptual approach) merupakan pendekatan yang didasarkan pada buku-buku ataupun literatur yang menjelaskan tentang hal-hal atau

5 Peter Mahmud Marzuki, Penelitian Hukum, Kencana Perdana Media, Surabaya, 2014, Hlm.60.

6 Ibid.,.Hlm.93. konsep-konsep yang dapat membantu dalam menganalisis kasus ini, seperti Konsep perubahan data fisik tanah, konsep pendaftaran tanah, konsep hak atas tanah, serta konsep penatagunaan tanah. Pendekatan ini dilakukan guna mengantisipasi jika belum terdapatnya aturan dan untuk lebih memudahkan dalam menyelesaikan permasalahan dalam studi kasus dalam penulisan ini.

Melalui latar belakang di atas tadi dapat dikemukakan rumusan masalah yang sekaligus menjadi tujuan dalam makalah ini yaitu :

a. Untukmengkajidanmenganalisis terkait akibat hukum yang ditimbulkan terhadap hak atas tanah yang tanahnya mengalami Perubahan Data Fisik tanah sebagai akibat dari hal yang tidak dikehendakinya.

b. Untukmengkajidanmenganalisis tentang prosedur dan upaya hukum pemerintah dalam mewujudkan asas keadilan dan kepastian hukum dalam hal menyusutnya luas tanah hak milik seseorang akibat pengaruh alam.

III. HASIL DAN PEMBAHASAN

3.1 Akibat Hukum Terhadap Tanah Hak Milik yang Mengalami Perubahan Data Fisik Tanah

Berdasarkan pasal 33 ayat 3 Undang-undang Dasar Negara Republik Indonesia Tahun 1945 
(UUD NRI 1945) menjelaskan bahwa "Bumi, Air, dan kekayaan alam yang terkandung di dalamnya dikuasai oleh Negara dan dipergunakan untuk sebesar-besarnya kemakmuran rakyat" maka dari itu tanah sudah seharusnya dipergunakan atau dimanfaatkan semaksimal mungkin. Hak milik atas tanah sebagai salah satu jenis hak atas tanah yang paling unggul bagi Negara, Bangsa, dan Rakyat Indonesia sebagai masyarakat agraria yang sedang membangun ke arah perkembangan industri dan bidang lainnya. Besar harapan masyarakat dengan memiliki hakterunggultersebutmakamasyarakat dapat melakukan suatu kegiatan yang berguna untuk kehidupannya.

Hak milik merupakan sumber kehidupan, oleh karena itu untuk dapat memenuhi kebutuhan hidup, harta benda tertentu harus dimiliki, karena bagi manusia, ada barang tertentu yang merupakan the natural media on which human existence depends. ${ }^{7}$ Roscoe Pound, mengungkapkan doktrin tentang pemilikan dalam arti yang luas, meliputi pula milik yang tak berwujud (incorporeal property) dan ajaran yang tumbuh berkembang mengenai perlindungan bagi hubungan ekonomi yang menguntungkan, memberikan efek kepada kebutuhan dan permintaan masyarakat. Dalam tataran masyarakat tradisional hanya

7 Roscoe Pound, An Introduction to the Philosophy, Yele University Press, New Haven, New York,1954, Hlm.117.; Lihat pula C.F.G Sunarjati Hartono, Beberapa Pemikiran Kearah Pembaruan Hukum Tanah ,Alumni, Bandung, 1978, hlm.52. diakui barang kepunyaan (natural possession, bezit), yang kemudian dalam perkembangan menjadi hak milik dalam arti yuridis. ${ }^{8}$

Hak milik atas tanah dapat lahir atau terjadi melalui tiga cara sebagaimana disebutkan dalam pasal 22 UUPA yaitu hak milik atas tanah yang lahir menurut hukum adat, penetapan pemerintah, dan ketentuan undang-undang. Jika hak milik yang lahir dari perspektif hukum adat maka maksudnya ialah hak milik atas tanah tersebut terjadi dengan jalan pembukaan tanah (pembukaan hutan) atau terjadi karena timbulnya lidah tanah (aanslibbing), dengan pembukaan tanah dilakukan secara bersama-sama dengan masyarakat hukum adat yang dipimpin oleh ketua adat melalui tiga sistem penggarapan yaitu, matok sirah matok galeng, matok sirah gilir galeng, dan sistem bluburan. Sedangkan yang dimaksud dengan lidah tanah (aanslibbing) adalah pertumbuhan tanah di tepi sungai, danau, atau laut, tanah yang tumbuh demikian itu dianggap menjadi kepunyaan orang yang memiliki tanah yang berbatasan, karena biasanya pertumbuhan tersebut sedikit banyak terjadi karena usahanya. ${ }^{9}$

Sebidangtanahdapatsajaberubah luas maupun bentuknya bukan hanya karena perbuatan subyek-subyek yang

$8 \quad$ Ibid., hlm.53.

9 Boedi Harsono, Hukum Agraria Indonesia Sejarah Pembentukan Undang-undang Pokok Agraria, isi, dan Pelaksanaannya, Djambatan, Jakarta, 2003, hlm.44. 
tidak bertanggung jawab, melainkan dapat terjadi akibat perubahan keadaan alam itu sendiri, tidak hanya dapat berdampak terjadinya perubahan data fisik pada tanah, hal ini juga dapat berdampak bertambah atau munculnya lidah tanah (aanslibbing) seperti dikarenakan surutnya air laut atau sungai sehingga meninggalkan lumpur yang mengeras dan menjadi tanah baru pada daerah pinggir pantai atau sungai, selain munculnya tanah, dan juga terjadi pengurangan atau lenyapnya tanah seperti halnya terjadinya suatu pengurangan luas tanah atau perubahan data fisik terhadap luas tanah.

Perubahandata fisikterhadapluas tanah ini juga dapat terjadi pada tanah apapun dan milik siapa pun, adapun beberapa faktor penyebab terjadinya perubahan data fisik terhadapluas tanah dapat terjadi dikarenakan oleh hal-hal seperti dilakukannya pengambilalihan lahan oleh pemerintah yang akan dipergunakan untuk pembangunan demi kepentingan umum, dengan begitu seorang pemegang hak atas tanah harus rela melepas sebagian atau seluruhnya hak atas tanahnya dengan diikuti suatu bentuk ganti kerugian oleh pihak pemerintah dengan perhitungan dan perbandingan yang sesuai dan layak dengan berdasar sebagaimana diatur pada sebuah asas hukum Aequum Pretium atau Iustum Pretium yang artinya suatu harga haruslah layak. ${ }^{10}$

10 IKetut Artadi,[et.al], Implementasi Ketentuanketentuan Hukum Perjanjian Kedalam Perancangan Kontrak, Udayana University Press, Denpasar, 2010, hlm.175.
Kemudian terkait dengan pelepasan hak atas tanah juga harus dilakukan dengan berdasarkan pada fungsi sosial pada tanah, bahkan pada tanah hak milik sekalipun. Berkenaan dengan fungsi sosial pada hak atas tanah, Boedi Harsono menjelaskan bahwa dalam penggunaan tanah itu harus mengutamakan kepentingan umum daripada kepentingan individu. Ini bukan berarti kepentingan individu dapat diabaikan begitu saja. Jika kepentingan umum mendesak suatu kepentingan individu yang mengakibatkan kepentingan individu tersebut menderita kerugian, maka dengan demikian harus diberikan suatu kompensasi ataupun ganti kerugian atas tanah haknya tersebut. ${ }^{11}$ Selain perubahan data fisik karena faktor diatas tadi, juga dapat terjadi suatu perubahan data fisik terhadap luas tanah yang diluar keinginan dan diluar dugaan pemegang hak atas tanah, misalnya suatu tanah yang terletak di tepi sungai, tepi pantai atau laut, yang diakibatkan erosi pinggir sungai maupun abrasi air laut, beberapa faktor-faktor perubahan data fisik terhadap luas tanah tersebut secara langsung memberi rasa takut dan resah terhadap pemegang hak milik atas tanah tersebut, karena dengan perubahan data fisik terhadap luas tanahnya tersebut maka dengan begitu tanahnya tidak dapat dimanfaatkan secara maksimal.

11 Boedi Harsono, Op.cit.,hlm.191. 
Sebagaimana yang diteliti dari kasus dalam tesis ini, yaitu sebidang tanah Hak Milik yang terletak di Jalan Dahlia, Desa Dalung, Banjar Tuka, Kecamatan Kuta Utara, Kabupaten Badung, Provinsi Bali. Tanah tersebut memiliki luas tanah $1000 \mathrm{~m}^{2}$, pada salah satu sisi perbatasan tanah tersebut ialah berbatasan dengan sebuah sungai kecil yang juga sering dijadikan tempat pengaliran akhir pada sistem pengairan sawah di sekitarnya, tanah tersebut memiliki gambar denah serta patok batas tanah yang jelas pada fakta di lapangan terkait batasbatas tanah yang jelas tersebut, tanah ini pun memiliki suatu permasalahan yakni ketika pemegang hak milik atas tanah tersebut ingin mendirikan sebuah bangunan semi permanen diatas tanahnya tersebut. Ketika akan mendirikan bangunan, pemegang hak milik atas tanah tersebut mendapat teguran dan larangan mendirikan bangunan diatas tanah miliknya sendiri oleh petugas Satuan Polisi Pamong Praja Daerah Kabupaten Badung. Adapun alasan teguran dan larangan tersebut adalah di karenakan lokasi untuk mendirikan bangunan tersebut seharusnya diperuntukkan sebagai sempadan sungai yang harus bebas dari bangunan apapun/dikosongkan. Jika secara yuridis, pemegang hak milik atas tanah tersebut mendirikan bangunan yang masih dalam batas wilayah tanah kepemilikannya sendiri, karena pemegang hak milik atas tanah tersebut mendirikan bangunan masih berada di dalam batas patok tanah kepemilikannya sendiri.

Setelah dilakukan penelitian terhadap data-data terkait objek penelitian, ternyata dahulu memang terdapat jarak antara sungai dengan tanah hak milik tersebut (atau yang biasa disebut sempadan sungai), namun saat ini sempadan sungai tersebut telah lenyap akibat tergerus air sungai hingga mengenai sebagian luas tanah milik warga tersebut, hal ini mengakibatkan luas tanah yang dimiliki warga tersebut menjadi menyusut/berkurang luasnya. Maka ini pun menjadi permasalahan yang juga menjadi suatu bahan kajian terhadap peraturan perundangundangan yang terkait untuk dapat membuktikan tentang kekuatan dari hak milik atas tanah tersebut, dan tentunya penyelesaian masalah ini tak luput dari peran pihak pemerintah yang memiliki kewenangan di bidang ini, seperti Kementerian Agraria dan Tata Ruang melalui Badan Pertanahan Nasional dan Kantor Pertanahan Kabupaten/Kota setempat.

Untuk dapat mengetahui pengertian dari perubahan data fisik pada tanah, dapat merujuk kepada bagian penjelasan pasal 36 ayat (1) PP 24/1997 ini menjelaskan bahwa perubahan data fisik terjadi kalau diadakan pemisahan, pemecahan, atau penggabungan bidang-bidang tanah yang sudah didaftar, dan perubahan data yuridis terjadi misalnya kalau diadakan pembebanan atau pemindahan hak atas bidang tanah yang sudah didaftarkan. 
Jika dilihat secara keseluruhan, maka yang diatur dalam pasal 36 ayat (1) dan (2) PP 24/1997 tersebut ialah tentang perubahan data fisik dan yuridis dengan kriteria yang dimaksud dalam penjelasannya, dan juga mengatur terkait kewajiban pemegang hak atas tanahuntuk segera mendaftarkan segala perubahan data fisik ataupun yuridis yang dilakukan pada bidang tanah yang dimilikinya. Perlu dilakukan suatu pendalaman dan penafsiran hukum terkait kejelasan peristiwa dan solusi dari terjadinya perubahan data fisik terhadap luas tanah ini dalam hal untuk mencapai dan mewujudkan asas kepastian hukum dalam hukum agraria pada umumnya dan tujuan dalam kegiatan pendaftaran tanah pada khususnya. Sehubungan dengan telah dilakukannya pengkajian dalam konsep hukum tentang perubahan data fisik terhadap luas tanah ini perlu dianalisis dan dalam hal ini tidak dapat dipisahkan dari konsep hukum terkait peran pemerintah dalam hal terjadinya suatu perubahan data fisik terhadap luas tanah.

Setiap tanah yang telah didaftarkan hak atas tanahnya tentu memiliki luas tanahnya masingmasing, salah satu alasan dilakukannya pendaftaranhakatastanahiniialahuntuk mendapatkan rasa kepastian hukum terhadap pemilik atau pemegang hak atas tanah sebagaimana yang dijanjikan dan dicita-citakan oleh UUPA maupun peraturan turunannya yaitu PP 24/1997 tersebut. Hal ini akan menjadi sulit dilakukan dikarenakan pertumbuhan dan perubahan kebutuhan terhadap tanah di masyarakat saat ini yang tidak diikuti dengan perkembangan peraturan perundang-undangan yang mampu untuk menciptakan suatu pengaturan yang dapat memberi rasa aman dan berkepastian hukum pula.

Terkait masih belum adanya pembaharuan peraturan perundangundangan tentang tanah di Indonesia, maka dengan terjadi suatu keadaan seperti kasus ini, jika merujuk pada peraturan yang ada, yaitu pasal 27 huruf $b$ UUPA menjelaskan bahwa sebuah tanah dinyatakan hapus hak miliknya ketika tanah tersebut musnah. Makna "tanahnya musnah" ini menimbulkan suatu multitafsir di kalangan masyarakat. Hal ini pun menjadi sebuah pengertian yang kabur pula dalam UUPA, sebagaimana yang dimaksud dengan pengertian yang kabur adalah tentang sebuah pengertian dapat dikatakan bahwa sebuah pengertian itu memiliki inti yang kurang jelas, yang lingkupnya dapat ditentukan secara persis, tetapi bahwa di sekelilingnya terdapat batas yang tidak jelas yang lingkupnya tidak dapat ditetapkan secara persis. ${ }^{12}$

Hal ini juga terjadi karena tidak diberinya suatu penjelasan atas pasal ini terkait ukuran atau batasan-batasan dari istilah musnah yang digunakan dalam pasal tersebut terkait bilamana

12 JJ.H.Bruggink diterjemahkan oleh B.Arief Sidharta, Refleksi Tentang Hukum PengertianPengertian Dasar Dalam Teori Hukum ,PT. Citra Aditya Bakti, Bandung, 2015, hlm.61. 
tanah tersebut dikatakan musnah dan dapat mengakibatkan hapusnya hak milik atas tanahnya tersebut. Namun berdasar pada kasus ini, pemerintah juga memiliki kepentingan untuk membuat suatu sempadan sungai yang memberi akibat untuk harus dipergunakannya sebagian luas tanah warga tersebut untuk dijadikan sempadan sungai. Maka untuk kasus ini tidak dapat dilihat dari satu sisi peraturan perundang-undangan saja, namun harus melihat kepada beberapa peraturan perundang-undangan lainnya yang berkaitan dengan kasus ini. Tugas penting bagi hakim dalam penemuan hukum guna menentukan peristiwa-peristiwa apa yang masih termasuk dalam pengertian-pengertian yang ditetapkan dalam undangundang dan yang mana tidak juga di sini jelas kejadian-kejadian yang secara tidak bermakna ganda termasuk dalam inti dari pengertian itu. ${ }^{13}$ Dalam hal norma kosong dan norma yang kabur, solusinya dilakukan oleh hakim melalui metode penafsiran hukum (penafsiran tata Bahasa, penafsiran sistematis, penafsiran sejarah hukum, penafsiran teleogi atau sosiologis) atau melalui konstruksi hukum (analogi, argumentum a contrario, rechtverifijning atau penghalusan hukum). ${ }^{14}$

Namun dalam hal menganalisis kasus ini, tidak cukup hanya dengan

13 Ibid., hlm.63.

14 I Dewa Gede Atmadja, Pengantar Penalaran Hukum dan Argumentasi Hukum, Bali Aga, Denpasar, 2009, hlm.35. melihat pada satu instrument peraturan perundang-undangan saja, melainkan dapat melihat kepada instrument peraturan perundang-undangan lainnya yang berkaitan dengan kasus ini, seperti dengan melihat pada aspek penatagunaan tanahnya, maksudnya adalah sesuai pada pasal 1 Peraturan Pemerintah Nomor 16 Tahun 2004 tentang Penatagunaan Tanah (PP 16/2004) menjelaskan bahwa, penatagunaan tanah ialah sama dengan pola pengelolaan tata guna tanah yang meliputi penguasaan, penggunaan, dan pemanfaatan tanah yang berwujud konsolidasi pemanfaatan tanah melalui pengaturan kelembagaan yang terkait dengan pemanfaatan tanah sebagai satu kesatuan system untuk kepentingan masyarakat secara adil. Dan juga aspek penatagunaan tanah lainnya dapat dilihat dalam pasal 2 PP 16/2004, menjelaskan bahwa penatagunaan tanah berdasarkan keterpaduan, berdayaguna, dan berhasilguna, serasi, selaras, seimbang, berkelanjutan, keterbukaan, persamaan, keadilan dan perlindungan hukum.

Dalam pasal 2 PP 16/2004 dapat dilihat bahwa salah satu tujuan dari penatagunaan tanah ialah agar dapat terciptanya suatu keseimbangan dan keselarasan antara alam dan manusia. Maka dengan itu penatagunaan tanah yang akan dilakukan oleh pemerintah Kabupaten Badung terhadap tanah Hak Milik salah seorang warga di sana ialah untuk dibuatkan suatu sempadan sungai, dengan berdasar pada Rencana Tata Ruang Wilayah yang ada. 
Dengan dipertegasnya peruntukan sebagian luas tanah tersebut sebagai sempadan sungai sesuai dengan Rencana Tata Ruang Wilayah setempat dan juga sesuai dengan penatagunaan tanah, maka pemegang hak milik atas tanah tersebut akan tetap memiliki tanahnya dengan status hak milik tersebut, tetapi pemilik tanah tersebut harus menghormati serta melaksanakan fungsi sosial dari tanah tersebut dan Rencana Tata Ruang Wilayah tersebut untuk menggunakan sebagian luas tanahnya yang termasuk dalam jarak sempadan tersebut agar dapat dipergunakan sebagaimana peruntukannya sebagai sempadan sungai.

Adapun cara lain yang dapat dilakukan ialah pemegang hak milik atas tanah tersebut dalam melakukan pelepasan hak atas tanah terhadap sebagian luas tanah hak miliknya agar menjadi Tanah Negara yang diikuti dengan diberikannya suatu bentuk dan besaran ganti kerugian oleh negara atas tanah hak milik yang telah dilepasnya melalui musyawarah yang dilakukan oleh para pihak yaitu Pihak Pemegang hak milik dan pihak pemerintah setempat, hal ini dilakukan agar negara dapat mempergunakan tanah yang dilepas haknya tersebut menjadi sempadan sungai dan pemegang hak milik atas tanah sebelumnya juga mendapat ganti kerugian yang layak.

\subsection{Langkah Hukum Yang Dapat Dilakukan Dalam Hal Menyusutnya}

Luas Tanah Hak Milik Akibat Pengaruh Alam

Pendaftaran tanah ialah suatu kegiatan yang dianggap dapat menjamin kepastian dan kekuatan hukum atas suatu hak atas tanah yang dimiliki, namun suatu kegiatan pendaftaran tanah tersebut tidak selamanya menjadi suatu langkah yang efektif dalam hal menjamin kepastian hukum terhadap kepemilikan suatu hak atas tanah, karena suatu pendaftaran hak atas tanah dengan tidak diikuti dengan adanya kegiatan pemeliharaan data pendaftaran tanah akan menjadi suatu permasalahan ke depannya. Hal ini disebabkan suatu keadaan tanah dapat berubah, baik perubahan fisik maupun secara yuridisnya, sehingga sangatlah diperlukan untuk dilakukannya kegiatan pemeliharaan data pendaftaran tanah ini.

Sebagaimana diatur dalam pasal 1 angka 12 PP 24/1997, bahwa yang dimaksud dengan pemeliharaan data pendaftaran tanah adalah kegiatan pendaftaran tanah yang dilakukan untuk menyesuaikan data fisik dan data yuridis dalam peta pendaftaran, daftar tanah, daftar nama, surat ukur, buku tanah, dan sertipikat dengan perubahan-perubahan yang terjadi kemudian.

Pemeliharaan data pendaftaran tanah ini dilakukan apabila terjadi perubahan pada data fisik atau data 
yuridis objek pendaftaran tanah yang telah terdaftar. Pemegang hak yang bersangkutan wajib mendaftarkan perubahan data fisik atau data yuridis tersebut kepada Kantor Pertanahan Kabupaten/Kota setempat untuk dicatat dalam buku tanah. ${ }^{15}$

Sebagaimana yang terjadi pada kasus ini, Lenyapnya sempadan sungai yang diakibatkan faktor alam erosi ini menyebabkan tidak adanya suatu kepastian hukum terhadap hak atas tanah akan di manfaatkan oleh pemiliknya, dan hal ini menjadi suatu polemik dalam hal tidak jelasnya status hak atas tanah yang dimiliki warga tersebut akibat perubahan data fisik terhadap luas tanah tersebut.

Jika melihat pada kasus diatas tadi, hal ini memang terjadi suatu perbedaan luas tanah pada surat ukur dan sertipikat dengan luas tanah pada faktualnya, hal ini terjadi perubahan dalam bentuk menyusutnya luas tanah hak milik yang tertera pada sertipikat yaitu $1000 \mathrm{~m}^{2}$ yang menjadi berkurang dari luas tanah semestinya tersebut. Namun perbedaan luas tanah pada sertipikat dengan pada luas tanah faktualnya ini terjadi bukanlah karena kesalahan administrasi kantor pertanahan ataupun teknis pengukurannya, namun ini terjadi karena suatu faktor pengaruh alam yaitu tergerusnya sempadan sungai hingga tanah hak milik warga akibat debit air sungai yang meningkat.

15 Urip Santoso (Selanjutnya Urip Santoso I), Pendaftaran dan Peralihan Hak Atas Tanah, Kencana Predana Media Group, Surabaya, 2010, hlm.35.
Dengan melihat permasalahan dalam kasus ini, maka hal ini membuat terciptanya ketidakpastian dalam terwujudnya sifat unggul pada hak milik atas tanah yaitu yang bersifat "terkuat dan terpenuh". Yang mana sifat keunggulan hak milik atas tanah ini diakui dan diatur menurut undangundang, tentunyahalini harusmendapat langkah penyelesaian dengan cara yang baik sehingga dapat menciptakan rasa adil dan aman bagi seluruh pihak, baik itu dari pihak pemilik hak atas tanah maupun pihak pemerintah setempat yang dalam hal ini bertugas untuk menjaga dan menegakkan pelaksanaan dan pembangunan tata ruang wilayah setempat.

Dalam kasus ini, menjadi suatu permasalahan yang menarik untuk dianalisis. Dalam hal ini para pihak (pemilik hak atas tanah dan pemerintah yang berwenang) sama-sama merasa memiliki kepentingan dalam menggunakan tanah tersebut. Di satu sisi, pihak pemegang hak milik atas tanah merasa berhak menggunakan tanahnya tersebut. Di sisi lain, pada pihak pemerintah setempat juga merasa harus melaksanakan ketentuan pembangunan dan tata ruang wilayah setempat.Keduabelahpihaksama-sama merasaberwenanguntukmenggunakan tanah yang sama, sehingga hal ini dapat memicu terjadinya sengketa. Sri Hajati berpendapat bahwa sengketa merupakan kelanjutan dari adanya suatu masalah, sebuah masalah akan menjadi sengketa bila masalah 
tersebut tidak diselesaikan. Sepanjang para pihak dapat menyelesaikan masalahnya dengan baik, maka sengketa tidak akan terjadi. Begitu pula sebaliknya, jika suatu kesepakatan mengenai pemecahan masalah tidak dapat tercapai, maka akan timbul sengketa. ${ }^{16}$

Dalam hal kegiatan pemeliharaan data pendaftaran tanah ini, jika melihat pengaturan dalam PP 24/1997 mengatur secara tersirat bahwa suatu bentuk perubahan data yuridis ataupun data fisik yang terjadi pada bidang tanah harus segera dilaporkan dan disampaikan untuk di data kembali/ pembaharuan data tanah ke kantor pertanahan kabupaten kota setempat, agar dapat di perbaharui dan dicatatkan pada buku tanah. Buku tanah adalah dokumen dalam bentuk daftar yang memuat data yuridis dan data fisik suatu objek pendaftaran tanah yang sudah ada haknya. ${ }^{17}$

Berkaitan dengan akibat hukum yang dapat ditimbulkan dari Perubahan Data Fisik tanah sebagian tadi, langkah hukum yang dapat dilakukan sebagai upaya preventif agar tidak kehilangan hak atas tanah lainnya juga dapat dilakukan. Adapun langkah hukum yang dapat dilakukan dalam hal ini yaitu dengan melakukan kegiatan

16 Sri Hajati,"Model Penyelesaian Sengketa Pertanahan Melalui Mediasi Dalam Mewujudkan Penyelesaian Yang Efesiensi Dan Berkepastian Hukum" Penelitian Unggulan Perguruan Tinggi Sumber Biaya Bantuan Operasional Perguruan Tinggi Negeri Fakultas Hukum Universitas Airlangga, Surabaya, 1 Nopember 2013, hlm.23.

17 Urip Santoso I, Op.cit., hlm.35. pemeliharaan data pendaftaran tanah.

Sebagaimana diatur dalam pasal 1 angka 12 PP 24/1997, bahwa yang dimaksud dengan pemeliharaan data pendaftaran tanah adalah kegiatan pendaftaran tanah yang dilakukan untuk menyesuaikan data fisik dan data yuridis dalam peta pendaftaran, daftar tanah, daftar nama, surat ukur, buku tanah, dan sertipikat dengan perubahan-perubahan yang terjadi kemudian.

Pemeliharaan data pendaftaran tanah ini dilakukan apabila terjadi perubahan pada data fisik atau data yuridis objek pendaftaran tanah yang telah terdaftar. Pemegang hak yang bersangkutan wajib mendaftarkan perubahan data fisik atau data yuridis tersebut kepada Kantor Pertanahan Kabupaten/Kota setempat untuk dicatat dalam buku tanah. ${ }^{18}$ Melalui kegiatan pemeliharaan data pendaftaran tanah ini diharapkan terus terjadinya pembaharuan kondisi tanah terkini agar mudah untuk di data. Namun dalam hal ini melakukan kegiatan pemeliharaan data pendaftaran tanah saja belum cukup untuk menyelesaikan permasalahan dalam studi kasus ini.

Setelah dilakukannya pemeliharaan data pendaftaran tanah dan melihat kembali pada aspek penatagunaan tanahnya, sesuai pada pasal 1 Peraturan Pemerintah Nomor 16 Tahun 2004 tentang Penatagunaan Tanah (PP 16/2004) menjelaskan bahwa, penatagunaan tanah ialah

18 Ibid. 
sama dengan pola pengelolaan tata guna tanah yang meliputi penguasaan, penggunaan, dan pemanfaatan tanah yang berwujud konsolidasi pemanfaatan tanah melalui pengaturan kelembagaan yang terkait dengan pemanfaatan tanah sebagai satu kesatuan system untuk kepentingan masyarakat secara adil.

Aspek penatagunaan tanah lainnya dapat dilihat dalam pasal 2 PP 16/2004, menjelaskan bahwa penatagunaan tanah berdasarkan keterpaduan, berdayaguna, dan berhasilguna, serasi, selaras, seimbang, berkelanjutan, keterbukaan, persamaan, keadilan dan perlindungan hukum. Dengan berdasar pada pengaturan ini dan dengan melihat kondisi fisik dan lokasi tanah yang diperuntukkan sebagai sempadan sungai dalam konteks penatagunaan tanahnya tersebut, maka sebagian luas tanah dari tanah hak milik warga tersebut haruslah dipergunakan sebagai sempadan sungai, atau dapat juga dilakukan langkah pelepasan sebagian luas tanah hak milik warga tersebut, agar menjadi tanah negara dan pemerintah setempat dapat memanfaatkan tanah negara tersebut untuk dijadikan sempadan sungai, namun kegiatan pelepasan hak pada sebagian luas tanah hak milik tersebut juga diikuti oleh kegiatan ganti kerugian oleh pemerintah juga.

Maka dengan itu, suatu kegiatan untuk melakukan ganti kerugian atas tanah tersebut dirasa mampu untuk menyelesaikan permasalahan ini. Dalam pasal 65 PERPRES 71/2012 ini menyatakan bahwa penilai bertugas untuk melakukan penilaian besarnya ganti kerugian bidang per bidang tanah, meliputi tanah, ruang atas tanah dan bawah tanah, bangunan, tanaman, benda yang berkaitan dengan tanah, dan kerugian lain yang dapat dinilai. Sehingga melalui pengaturan pasal tersebut dapat diambil kesimpulan bahwa tanah merupakan objek untuk dapat diberikan ganti kerugian dan dapat dinilai harganya. Begitu halnya dengan bentuk dari ganti kerugian yang dapat diberikan, pada pasal 74 dalam PERPRES 71/2012 menyatakan bahwa ;

(1) Pemberian ganti kerugian dapat diberikan dalam bentuk;
a. uang;
b. tanah pengganti;
c. pemukiman kembali;
d. kepemilikan saham, atau;
e. bentuk lain yang disetujui oleh kedua belah pihak.

(2) Bentuk ganti kerugian sebagaimana dimaksud pada ayat (1), baik berdiri sendiri maupun gabungan dari beberapa bentuk ganti kerugian, diberikan sesuai dengan nilai ganti kerugian yang nominalnya sama dengan nilai yang ditetapkan oleh penilai.

Dengan ditetapkannya aturan terkait bentuk ganti kerugian dalam PERPRES 71/2012 ini memberi kejelasan dan mempermudah dalam langkah untuk memberi ganti kerugian 
atas tanah tersebut. Begitu pula halnya terkait tata cara dalam pemberian ganti kerugian atas tanah diatur pada pasal 68 dalam PERPRES 71/2012 yang menjelaskan bahwa, pelaksana pengadaan tanah melaksanakan musyawarah dengan pihak yang berhak dalam waktu paling lama 30 (tiga puluh) hari sejak hasil penilaian dari Penilai Pertanahan diterima oleh Ketua Pelaksana Pengadaan Tanah.

Kemudian Dalam pasal 69 PERPRES 71/2012 mengatur bahwa Pelaksana Pengadaan Tanah mengundang para pihak yang berhak dalam musyawarah penetapan ganti kerugian dengan menetapkan tempat dan waktu pelaksanaan. Musyawarah ini dipimpin oleh ketua pelaksana pengadaan tanah atau pejabat yang ditunjuk. Pelaksanaan musyawarah ini dilakukan dengan mengikutsertakan instansi yang memerlukan tanah. Musyawarahdilakukansecaralangsung untuk menetapkan bentuk ganti kerugian berdasarkan hasil penilaian ganti kerugiannya. Kemudian pada pasal 72 dalam PERPRES 71/2012 menyatakan bahwa hasil kesepakatan dalam musyawarah menjadi dasar pemberian ganti kerugian kepada pihak yang berhak yang dituangkan dalam berita acara kesepakatan. ${ }^{19}$

Dalam proses musyawarah terkait pemberian bentuk dan/atau besaran ganti kerugian tersebut dapat

19 Urip Santoso (selanjutnya Urip Santoso II), Hukum Pengadaan Tanah Untuk Kepentingan Umum, Airlangga University Press, Surabaya, 2013, hlm. 80 . mencapai beberapa hasil di akhir antara lain tercapainya atau tidak tercapainya bentuk dan/atau besaran ganti kerugian atas tanahnya tersebut. Dalam hal tidak tercapainya kesepakatan terkait bentuk dan/atau besarnya ganti kerugian dalam musyawarah yang di putuskan, maka, pihak yang berhak dapat mengajukan keberatan kepada pengadilan negeri setempat dalam kurun waktu paling lama 14 hari kerja setelah ditandatanganinya berita acara hasil musyawarah. Pengadilan negeri memutus bentuk dan/atau besarnya ganti kerugian dalam waktu paling lama 30 hari kerja sejak diterimanya pengajuan keberatan tersebut. Kemudianjikapihakyangberhakmasih tidak puas dengan putusan pengadilan negeri, maka dapat melakukan upaya hukum kasasi ke Mahkamah Agung.

\section{KESIMPULAN}

1. Dalam pasal 27 UUPA hanya mengatur tentang hapusnya hak milik atas tanah yang salah satunya diakibatkan oleh musnahnya tanah, Namun aturan ini tidak menjadikan hak milik atas tanah sebagaimana dalam kasus ini menjadi hapus. Dengan ditinjau dari instrumen peraturan perundang-undangan lainnya yang berkaitan dengan kasus ini seperti UUPR, PP 16/2004, dan RTRW setempat, menjadikan kejelasan status dan peruntukan tanah yaitu dapat tetap menjadi tanah hak 
milik atas warga tersebut, tetapi dengan memperhatikan penggunaan tanah yang sesuai peruntukannya yaitu untuk sempadan sungai, atau dengan melepas sebagian luas tanah menjadi tanah negara dan mendapat ganti kerugian yang layak, agar tanah yang dilepas tersebut dapat dipergunakan sesuai dengan peruntukannya yaitu untuk sempadan sungai.

2. Jika terjadinya suatu perubahan data fisik terhadap luas tanah seluruhnya ataupun sebagian, maka pemegang hak milik dapat melakukan salah satu dari kegiatan pendaftaran tanah yaitu dengan melakukan pemeliharaan data pendaftaran tanah. Langkah hukum yang dapat dilakukan terhadap luas tanah menyusut akibat tergerus air sungai yang mengakibatkan perubahan data fisik tanah yaitu dengan langkah melihat peraturan dan peruntukan dalam penggunaan tanah tersebut sebagai sempadan sungai, dan pemerintah dapat mengambil langkah memberi suatu ganti kerugian melalui musyawarah antara pemegang hak milik dengan pemerintah, karena dalam hal ini pemerintah juga perlu menjalankan rencana tata ruang wilayah yang baik, seperti membuat jarak/sempadan sungai.

\section{DAFTAR PUSTAKA}

\section{Buku}

Artadi, I Ketut, I Dewa Nyoman Rai Asmara Putra, 2010, Implementasi Ketentuanketentuan Hukum Perjanjian Kedalam Perancangan Kontrak, Udayana University Press, Denpasar.

Atmadja, I Dewa Gede, 2009, Pengantar Penalaran Hukum dan ArgumentasiHukum,Bali Aga, Denpasar.

Harsono, Boedi, 2003, Hukum Agraria Indonesia Sejarah Pembentukan Undang-undang Pokok Agraria, isi, dan Pelaksanaannya, Djambatan, Jakarta.

Marzuki, Peter Mahmud, 2014, Penelitian Hukum, Kencana Perdana Media, Surabaya.

Pound,Roscoe, 1954, An Introduction to the Philosophy (Yele University Press,

New Haven, New York, Lihat pula C.F.G Sunarjati Hartono, 1978, Beberapa Pemikiran Ke arah Pembaruan Hukum Tanah, Alumni, Bandung.

Santoso,Urip, 2010, Pendaftaran dan Peralihan Hak Atas Tanah, Kencana Predana Media Group. Santoso,Urip,2013,HukumPengadaan Tanah Untuk Kepentingan Umum Airlangga University Press, Surabaya. 


\section{Buku Terjemahan}

Bruggink, JJ.H, diterjemahkan oleh B.Arief Sidharta, 2015, Refleksi Tentang Hukum PengertianPengertian Dasar Dalam Teori Hukum, PT. Citra Aditya Bakti, Bandung.

\section{Artikel Seminar Ilmiah}

Hajati, Sri, 2013, "Model Penyelesaian

Sengketa Pertanahan Melalui

Mediasi Dalam Mewujudkan

Penyelesaian Yang EfesiensiDan

Berkepastian Hukum", Dalam

Penelitian Unggulan Perguruan

Tinggi Sumber Biaya Bantuan Operasional Perguruan Tinggi

Negeri, Surabaya, 1 Nopember.

\section{Artikel Majalah Ilmiah Versi Online}

Adnyana, Penggunaan Kuasa Menjual Didalam Peralihan Hak Milik Atas Tanah Melalui JualBeli, Jurnal Magister Hukum Udayana (Udayana Master Law Journal), Vol.4, No.1:179-189 Edisi Mei 2015,https://ojs.unud. ac.id/index.php/jmhu/article/ view/13050, diakses tanggal 12 Oktber 2017.

Anak Agung Istri Diah Mahadewi, Pengaturan Prosedur Pembatalan Sertipikat Hak Atas Tanah Yang Merupakan Barang Milik Negara, Jurnal Magister Hukum Udayana (Udayana Master Law Journal), Vol.2 No.3 Edisi November 2013, https://ojs. unud.ac.id/index.php/jmhu/ article/view/7285, diakses tanggal 12 Oktober 2017.

I Wayan Werasmana Sancaya, Kekuatan Mengikat Perjanjian Nominee Dalam Penguasaan Hak Milik Atas Tanah, Jurnal Magister Hukum Udayana (Udayana Master Law Journal), Vol.2No.3EdisiNovember2013, https://ojs.unud.ac.id/index.php/ $\mathrm{jmhu} /$ article/view/7364, diakses tanggal 12 Oktober 2017.

\section{Peraturan Perundangan}

Undang-undang Dasar Negara Republik Indonesia Tahun 1945.

Undang-undang Nomor 5 Tahun 1960 tentang Peraturan Dasar Pokokpokok Agraria (Lembaran Negara Republik Indonesia Nomor 104 Tahun 1960).

Undang-undang Nomor 2 Tahun 2012 tentang Pengadaan Tanah Bagi Pembangunan Untuk Kepentingan Umum. (Lembaran Negara Republik Indonesia Nomor 22 Tahun 2012, Tambahan Lembaran Negara Republik Indonesia Nomor 5280).

Peraturan Pemerintah Nomor 24 Tahun 1997 tentang Pendaftaran Tanah (Lembaran Negara Republik Indonesia Nomor 59 Tahun 1997).

Peraturan Presiden Republik Indonesia Nomor 71 Tahun 2012 tentang 
Penyelenggaraan Pengadaan

Tanah Bagi Pembangunan untuk

Kepentingan Umum (Lembaran

Negara Republik Indonesia

Nomor 156 Tahun 2012).

Peraturan Menteri Agraria/ Kepala

Badan Pertanahan Nasional

Nomor 3 Tahun 1997 tentang

Ketentuan Pelaksanaan dari

Peraturan Pemerintah Nomor 24

Tahun 1997 tentang Pendaftaran

Tanah (Lembaran Negara

Republik Indonesia Tahun 1997). 